\title{
Water relations and gas exchange in Coespeletia moritziana (Sch. Bip) Cuatrec., a giant rosette species of the high tropical Andes
}

\author{
F. RADA ${ }^{*,+}$, A. AZÓCAR ${ }^{*}$, and A. ROJAS-ALTUVE ${ }^{* *}$ \\ Instituto de Ciencias Ambientales y Ecológicas, Facultad de Ciencias, Universidad de Los Andes. Mérida, Venezuela ${ }^{*}$ \\ Departamento de Cristalografía y Biología Estructural, Instituto de Química-Física "Rocasolano", CSIC, Serrano 119, \\ 28006-Madrid, Spain ${ }^{* *}$
}

\begin{abstract}
Giant rosettes are ones of the most striking features of the vegetation in the high tropical Andes, with Coespeletia moritziana reaching the highest altitudes up to 4,600 $\mathrm{m}$ a.s.l. Different from other giant rosettes, this species grows on rock outcrops with poorly developed soils and where water availability may be limited. Two questions are addressed in this study: How does this species respond in terms of water relations to maintain favorable gas-exchange conditions? Considering that adult plants rely on a water-reserving central pith, how do early stages respond to this environment's extreme conditions? Water relations and gas-exchange studies were carried out on juveniles, intermediate and adult C. moritziana plants during wet and dry seasons in Páramo de Piedras Blancas at 4,200 m a.s.l. Adult plants maintained higher leaf water potentials $\left(\Psi_{\mathrm{L}}\right)$ during the wet season, however, no differences between stages were found for the dry season. Minimum dry season $\Psi_{\mathrm{L}}$ were never near the turgor loss point in any of the stages. Juveniles show a more strict stomatal control during the dry season to maintain a favorable water status. Net photosynthesis significantly decreased in intermediate and juvenile stages from wet to dry seasons. Our results suggest that $C$. moritziana resists more extreme conditions compared to other Andean giant rosettes.
\end{abstract}

Additional key words: net photosynthetic rate; osmotic adjustment; plant growth stages; stomatal conductance; tropical mountains.

\section{Introduction}

Tropical high mountains combine an assortment of unique features to produce a very particular environment. Temperature plays an essential role in the existence of different plant life forms. Below zero temperatures may occur any night of the year, while daytime high incoming radiation inputs, with a greater frequency during the dry season, may generate high temperature conditions at leaf surfaces and near the ground. These conditions led Hedberg (1964) to describe this environment as one where summer occurs every day and winter every night of the year. In addition, water availability and high evaporative demand conditions are also critical features which determine plant survival at these altitudes. A distinctive dry season lasts from 2 to 4 months. Also, extremely low relative humidities, together with high solar radiation inputs determine a significant difference between leaf and air temperatures, leading to large water vapor pressure differences, which in turn have an impact on plant gas-exchange responses. Both temperature and water effects act differentially along soil level to air gradients. Therefore, plant survival may also be dependent on differential responses throughout the growing stages.

The páramos, in a very broad sense, may be defined as a characteristic ecosystem of the tropical high Andes composed mainly of low strata vegetation dominated by shrubs, grasses and giant rosettes. Within this latter plant life form, different species of the genus Coespeletia reach the highest altitudes of the high tropical Andes up to 4,600 $\mathrm{m}$. As adults, these plants consist of a single rosette of large pubescent leaves supported by an erect, unbranched stem which in some cases may reach a few meters. This stem holds a large central parenchymatic pith and is protected by a large layer of marcescent leaves. It is interesting to point out that this life form, presenting very similar structures, has evolved in other

Received 28 April 2011, accepted 26 April 2012.

${ }^{+}$Corresponding author; tel.: (58) 274 2441575, fax: (58) 274 2401255, e-mail: frada@ula.ve

Abbreviations: $E$ - transpiration rate; $g_{\mathrm{s}}$ - stomatal conductance; $\mathrm{L}$ - leaf area; $P_{\mathrm{N}}$ - net photosynthetic rate; PPFD - photosynthetic photon flux density; $\mathrm{RH}$ - relative humidity; $\mathrm{T}_{\mathrm{a}}$ - air temperature; $\mathrm{T}_{\mathrm{L}}$ - leaf temperature; $\mathrm{V}$ - chamber volume; VPD - leaf to air vapor pressure difference; WUE - water-use efficiency; $\Delta \mathrm{CO}_{2}$ - difference in $\mathrm{CO}_{2}$ concentration; $\Delta$ time - difference in time; $\Psi_{\mathrm{L}}$ - leaf water potential; $\Psi_{\mathrm{L}}{ }^{\mathrm{min}}-$ minimum leaf water potential; $\Psi_{\pi}{ }^{0}-$ osmotic potential at turgor loss. 
tropical high mountain regions of the world (Hedberg and Hedberg 1979, Halloy 1983, Smith and Young 1987, Bussmann 2006), suggesting that they have developed as a response to a tropical environment characterized by extreme daily temperature fluctuations, frequent night frosts, seasonal and daily water availability limitations and high incoming radiation inputs.

Night-time low temperature resistance has been studied for many of the giant rosettes of the Venezuelan high Andes (Goldstein et al. 1985b, Rada et al. 1985). In all cases, a high supercooling capacity of the leaves together with isolating marcescent leaf layers protecting stems, permit these rosettes to avoid freezing of their tissues. However, giant rosettes species of the African tropical mountains (Dendrosenecio and Lobelia spp.) are able to tolerate ice formation in leaf tissues (Beck et al. 1984). With respect to daytime temperature, water availability, and evaporative demand studies, Goldstein et al. (1984) described how adult giant rosettes depend on a high capacitance generated by the water-storage pith in order to resist water deficit periods. In addition, Rada et al. $(1987,1998)$ and Goldstein et al. (1989) showed how Espeletia schultzii, Coespeletia timotensis and Coespeletia spicata rely on strong stomatal control to avoid large water losses under high water vapor pressure differences between leaf and air, mainly during the dry season. Both of these responses result in the maintenance of high $\Psi_{\mathrm{L}}$ throughout the year with the accompanying cost in reductions of net photosynthetic rates. Low net photosynthetic rates were described for Andean giant rosette species (Baruch 1979, Baruch and Smith 1979, Goldstein et al. 1989, Rada et al. 1998). Schulze et al. (1985) described relatively high net photosynthetic rates for different giant rosette species of the Afroalpine vegetation. It is important to mention that most major studies on giant rosette plants worldwide have been

\section{Materials and methods}

Study site and plant characteristics: The study was carried out in the Páramo de Piedras Blancas $\left(08^{\circ} 52^{\prime} \mathrm{N}\right.$, $70^{\circ} 48^{\prime} \mathrm{S}$ ) at an altitude of 4,200 $\mathrm{m}$. This area corresponds to an open vegetation páramo (mainly rosette-shrub associations) of the Desert Páramo (Monasterio 1980) with different species of the genus Coespeletia with their characteristic tall stems $(1-3 \mathrm{~m})$ and narrow oblonglanceolate pubescent leaves. Bare soils may vary between 50 and $90 \%$. Mean annual temperature is $2.8^{\circ} \mathrm{C}$ with little seasonal variation and extreme daily variations with maximum above $30^{\circ} \mathrm{C}$ and night minimum below $-10^{\circ} \mathrm{C}$. Mean annual precipitation is $790 \mathrm{~mm}$ falling mainly between April and December and a marked dry season between December and March.

As previously mentioned, C. moritziana grows on rock outcroppings with well drained and poorly developed soils. Three well differentiated size classes were selected: juvenile, intermediate, and adult stages. carried out on adult plants. Responses of early establishing or nonreproductive stages of these rosette plants have been scarcely described for C. spicata and C. timotensis in the literature (Estrada et al. 1991, Goldstein et al. 1985a). These authors consider only water relations aspects and to our knowledge no gasexchange results have been presented.

C. moritziana is distributed between 4,000 and $4,600 \mathrm{~m}$ a.s.l. and mainly associated to rock outcrops with poorly developed soils presenting a large quantity of fractured rocks. Due to these characteristics, water availability may be limited. As stated previously, all described Andean giant rosette species avoid drought and/or high evaporative demand conditions through very strict stomatal control and a high capacitance obtained through the large water reservoirs of the central pith. Due to the more extreme conditions in which this species is found, several questions are addressed in this study: Does it respond, as all other giant rosettes, through a severe stomatal control during the unfavorable periods, or does it resist lower plant water potentials in order to maintain favorable gasexchange conditions? Considering that the environment near the ground is more extreme, and that smaller rosettes have not yet formed a large water reserving central pith, how do these stages respond to the extreme conditions previously described? Additionally, Azócar et al. (2000) describe how all Andean giant rosettes respond to water and temperature stresses in a similar manner, and therefore they suggest that any change in the environmental conditions, i.e. harsher water-stress conditions, would affect them as an important functional group of the páramo. As a consequence, this ecosystem would be functionally unstable under present climate change scenarios. Does this species fall outside of the general pattern described for all giant rosette species?

$\begin{array}{llll}\text { Stage } & \begin{array}{l}\text { Rosette diameter; } \\ \text { plant height }[\mathrm{cm}]\end{array} & \begin{array}{l}\text { Leaf length } \\ {[\mathrm{cm}]}\end{array} & \begin{array}{l}\text { Leaf width } \\ {[\mathrm{cm}]}\end{array} \\ \text { Juvenile } & 20-25 ; 20-25 & 15-18 & 0.8-1.5 \\ \text { Intermediate } & 30-35 ; 30-35 & 20-25 & 1.5-2.5 \\ \text { Adult } & 55-60 ; 90-100 & 25-30 & 2.0-2.5\end{array}$

Juveniles grew close to the ground and did not show an apparent stem and rosettes appeared sessile. Intermediate plants had an early developing stem. Adult individuals presented a well-developed stem of approximately $40 \mathrm{~cm}$ in length, covered with marcescent leaves. Adult individuals were the only ones that had any signs of earlier reproductive events.

Three daily courses of water relations and gasexchange measurements were carried out during each the month of February for the dry and between July and November for the wet seasons. All measurements were done at $1-1.5 \mathrm{~h}$ intervals for all courses. It is important to 
point out that measurement times for all wet season courses, on one hand, and all the dry season courses, on the other, were done at exactly the same hour periods, therefore, results presented correspond to means for each hour of the three daily courses considered for each season.

Microclimatic variables: Daily courses of microclimatic variables (air temperature $\left(\mathrm{T}_{\mathrm{a}}, n=3\right)$, relative humidity $(\mathrm{RH}, n=3)$ and photosynthetic photon flux density (PPFD, $n=3$ ) and leaf temperatures $\left(\mathrm{T}_{\mathrm{L}}, n=3\right.$ ) were carried out. $\mathrm{T}_{\mathrm{a}}$ and $\mathrm{T}_{\mathrm{L}}$ were measured with copperconstantan thermocouples connected to a digital thermometer for all three developmental stages. RH was measured with a digital hygrometer at the different plant heights. $\mathrm{T}_{\mathrm{a}}, \mathrm{T}_{\mathrm{L}}$, and $\mathrm{RH}$ were used to calculate leaf-to-air vapor pressure difference (VPD). PPFD was obtained through the selenium photocell of the leaf chamber of the gas-exchange system described further ahead.

Water relations: $\Psi_{\mathrm{L}}$ was measured in each of the studied daily cycles. Two leaves from three individuals in each size category were selected. Measurements were carried out with a pressure bomb (Model 600, PMS Instruments Inc., Corwallis, Oregon, USA).

Seasonal pressure-volume curves were generated to observe differences in osmotic potential at turgor loss $\left(\Psi_{\pi}^{0}\right)$ in order to determine if there were any osmotic adjustments between seasons. Leaves from the three stages were collected in the field, placed in containers and then recut under water. The containers were covered with plastic bags to avoid water losses through transpiration and transported to the laboratory where they remained in dark for $16 \mathrm{~h}$ to obtain complete saturation. Leaf water potential at saturation and leaf mass were initially determined and leaves were placed on the laboratory bench in order to let them transpire. Thereafter, $\Psi_{\mathrm{L}}$ and leaf mass were continuously determined until changes in $\Psi_{\mathrm{L}}$ between measurements towards the end of the experiment were consistently small from one hour to the next. Leaves were then oven dried at $60^{\circ} \mathrm{C}$ to obtain dry mass. $\Psi_{\mathrm{L}}$ components were obtained through the methods proposed by Tyree and Hammel (1972).

Gas exchange: Net photosynthetic rate $\left(P_{\mathrm{N}}\right)$, transpi-

\section{Results}

Differences in $\Psi_{\mathrm{L}}$ between stages were more pronounced during the wet season (Table 1, Fig. 1). Adult plants showed less negative $\Psi_{\mathrm{L}}$ between midmorning and early afternoon compared to intermediate or juvenile plants. These higher $\Psi_{\mathrm{L}}$ may be explained by lower VPD (nonsignificant trend) and significant differences in $g_{\mathrm{s}}$, giving rise to significantly lower $E$ in adult plants compared to the other two stages (Table 2). With respect to the dry season, VPD conditions were significantly higher compared to the wet season, while no significant differences ration rate $(E)$, and stomatal conductance $\left(g_{\mathrm{s}}\right)$ were measured on two completely developed leaves of three different individuals for each of the categories. A portable system ( $L C A-4, A D C L t d$., Hoddesdon, UK) consisting of a leaf chamber and an infrared gas analyzer unit, operating in an open mode was used. All measurements were made under ambient conditions with $\mathrm{CO}_{2}$ and water vapor circulating through the leaf chamber being supplied via a 5 -m air probe. Mean ambient $\mathrm{CO}_{2}$ concentration did not show significant differences between seasons in any of the size classes, with means of $359.9 \pm 2.6$ for the wetand $355.9 \pm 3.3$ for the dry season. Mean relative humidity within the leaf chamber was $82.7 \pm 5.0 \%$ during the wet- and $54.6 \pm 3.9 \%$ during the dry season for all size classes. Leaves were sealed within the chamber for approximately $30 \mathrm{~s}$, time in which stable measurements were obtained. Gas-exchange rates were determined according to von Caemmerer and Farquhar (1981).

PPFD- $P_{\mathrm{N}}$ curves for both wet- and dry seasons were constructed using field data. In addition, a $P_{\mathrm{N}}-\mathrm{T}_{\mathrm{L}}$ curve was constructed for adult plants from data obtained in the laboratory. Several adult plants $(n=3)$ were excavated from the study site and transported to the laboratory. Curves were carried out using a gas-exchange system with an infrared gas analyzer ( $L C A-2, A D C L t d$., Hoddesdon, UK) and a plant chamber $\left(0.014 \mathrm{~m}^{3}\right)$. The chamber was equipped with copper-constantan thermocouples connected to a digital thermometer. A 1,000 $\mu \mathrm{mol} \mathrm{m} \mathrm{m}^{-2} \mathrm{~s}^{-1}$ light source was placed above the chamber. A refrigerated bath with hose connections to a radiator installed within the chamber was used to increase and decrease $T_{a}$ and consequently $T_{L}$. Five leaves from a single rosette were placed within the chamber. Measurements were done at 1 -min intervals for $5 \mathrm{~min}$ at each chosen temperature. Plants were left 10-15 min at each set temperature. $P_{\mathrm{N}}$ was determined through $\mathrm{CO}_{2}$ depletion from the chamber and calculated through:

$$
P_{\mathrm{N}}=\mathrm{V} \Delta \mathrm{CO}_{2} /(\mathrm{L} \Delta \text { time }),
$$

where $\mathrm{V}$ is the chamber volume $\left[\mathrm{m}^{3}\right], \mathrm{L}$ is the leaf area $\left[\mathrm{m}^{2}\right], \Delta \mathrm{CO}_{2}$ corresponds to differences in $\mathrm{CO}_{2}$ concentration $\left[\mu \mathrm{mol} \mathrm{m} \mathrm{m}^{-3}\right]$ and $\Delta$ time to differences in time $[\mathrm{s}]$ (Field et al. 1989).

were observed between stages (Table 2, Fig. 1). Lower $\Psi_{L}$ were obtained for the dry season, however, no significant differences between stages were observed throughout the daily courses, showing similar minimum leaf water potentials $\left(\Psi_{\mathrm{L}}^{\mathrm{min}}\right)$ at midday. Juveniles showed a more severe stomatal control during the dry season, closing stomata after early morning maximum leaf conductances and reaching lowest $g_{\mathrm{s}}$ at midday (Fig. 1). Even though $\Psi_{\mathrm{L}}$ were much lower during the dry season in all stages, none of them fell close to the turgor loss 


\section{F. RADA et al.}

Table 1. Mean $\left(\Psi_{\mathrm{L}}{ }^{\text {mean }}\right)$ and minimum $\left(\Psi_{\mathrm{L}}{ }^{\mathrm{min}}\right)$ leaf water potential, and osmotic potential at the turgor loss point $\left(\Psi_{\pi}^{0}\right)$ for the different growth stages of Coespeletia moritziana during both wet and dry seasons. Values presented correspond to mean \pm SE ( $n=6$ for the wet and $n=7$ for the dry season). Different superscript letters correspond to significant seasonal differences for each parameter within each stage (U-Mann-Whitney, $p<0.05)$. Different superscript numbers correspond to significant differences between growth stages for each season (Kruskal-Wallis, $p<0.05)$.

\begin{tabular}{lllll}
\hline Stage & Season & $\Psi_{\mathrm{L}}^{\text {mean }}[\mathrm{MPa}]$ & $\Psi_{\mathrm{L}}^{\min }[\mathrm{MPa}]$ & $\Psi_{\pi}^{0}[\mathrm{MPa}]$ \\
\hline Adult & Wet & $-0.78 \pm 0.04^{\mathrm{a}, 1}$ & $-1.12 \pm 0.08^{\mathrm{a}, 1}$ & $-1.69 \pm 0.13^{\mathrm{a}, 1}$ \\
& Dry & $-1.39 \pm 0.06^{\mathrm{b}, 1}$ & $-1.84 \pm 0.06^{\mathrm{b}, 1}$ & $-2.30 \pm 0.07^{\mathrm{b}, 1}$ \\
\multirow{3}{*}{ Intermediate } & Wet & $-0.90 \pm 0.04^{\mathrm{a}, 2}$ & $-1.18 \pm 0.07^{\mathrm{a}, 1}$ & $-2.10 \pm 0.04^{\mathrm{a}, 2}$ \\
& Dry & $-1.46 \pm 0.04^{\mathrm{b}, 1}$ & $-1.90 \pm 0.06^{\mathrm{b}, 1}$ & $-2.35 \pm 0.04^{\mathrm{b}, 1}$ \\
Juvenile & Wet & $-0.94 \pm 0.04^{\mathrm{a}, 2}$ & $-1.12 \pm 0.08^{\mathrm{a}, 1}$ & $-1.93 \pm 0.08^{\mathrm{a}, 1,2}$ \\
& Dry & $-1.43 \pm 0.06^{\mathrm{b}, 1}$ & $-1.84 \pm 0.06^{\mathrm{b}, 1}$ & $-2.30 \pm 0.14^{\mathrm{b}, 1}$ \\
\hline
\end{tabular}

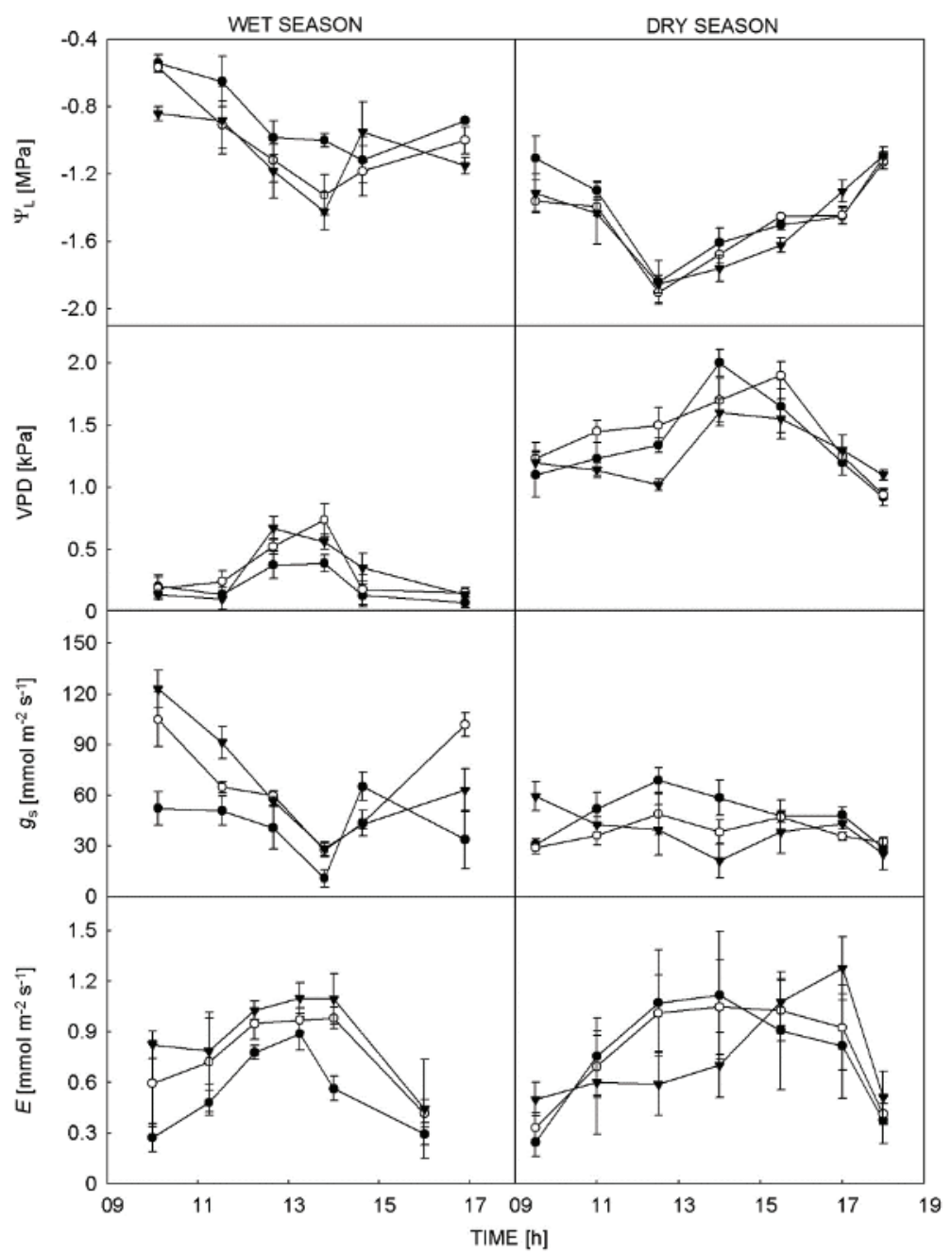

Fig. 1. Wet- and dry season courses for the different water relations parameters measured in the study: Leaf water potential $\left(\Psi_{\mathrm{L}}\right)$, vapor pressure difference between leaf and air (VPD), leaf stomatal conductance $\left(g_{\mathrm{s}}\right)$ and transpiration rate $(E)$. Results correspond to the mean of three different daily courses taken for each of the seasons. Adults $(\mathbf{O})$, intermediate $(\bigcirc)$, juveniles $(\boldsymbol{\nabla})$. Values presented correspond to mean $\pm \mathrm{SE}(n=9$ for both wet- and dry seasons).

point which was approximately $-2.3 \mathrm{MPa}$ for all stages (Table 1). Adult plants showed an important degree of seasonal osmotic adjustment with an approximate difference of $0.6 \mathrm{MPa}$ between wet and dry season. Whereas, intermediate and juvenile stages showed a slight adjustment between 0.2 and $0.4 \mathrm{MPa}$ from wet- to dry seasons due to the significantly lower $\Psi_{\mathrm{L}}$ at turgor loss during the wet season.
Incoming PPFD is much higher during the dry season resulting in higher $\mathrm{T}_{\mathrm{L}}$ (Table 2, Fig. 2), lower RH (data not presented) and, therefore, higher VPD (Table 2). Even though adult plants decreased $P_{\mathrm{N}}$ from wet to dry season, differences were not significant, while intermediate and juvenile stages significantly decreased their photosynthetic rates. In relation to water use efficiency (WUE), the juvenile stage was the only one showing 
Table 2. Mean photosynthetic photon flux density (PPFD), leaf temperature $\left(\mathrm{T}_{\mathrm{L}}\right)$, vapor pressure difference between leaf and air (VPD), leaf stomatal conductance $\left(g_{\mathrm{s}}\right)$, transpiration rate $(E)$, net photosynthetic rate $\left(P_{\mathrm{N}},\right)$ and water-use efficiency (WUE) for the different growth stages of Coespeletia moritziana during both wet- and dry seasons. Values presented correspond to mean \pm SE $(n=6$ for the wet- and $n=7$ for the dry season). Different superscript letters correspond to significant seasonal differences for each parameter within each stage $(U$-Mann-Whitney, $p<0.05)$. Different superscript numbers correspond to significant differences between growth stages for each season (Kruskal-Wallis, $p<0.05$ ).

\begin{tabular}{lllllllll}
\hline Stage & Season & $\begin{array}{l}\text { PPFD } \\
{\left[\mu \mathrm{mol} \mathrm{m}^{-2} \mathrm{~s}^{-1}\right]}\end{array}$ & $\mathrm{T}_{\mathrm{L}}\left[{ }^{\circ} \mathrm{C}\right]$ & $\mathrm{VPD}[\mathrm{kPa}]$ & $g_{\mathrm{s}}\left[\mathrm{mmol} \mathrm{m}^{-2} \mathrm{~s}^{-1}\right]$ & $\begin{array}{l}E \\
{\left[\mathrm{mmol} \mathrm{m}^{-2} \mathrm{~s}^{-1}\right]}\end{array}$ & $\begin{array}{l}P_{\mathrm{N}} \\
{\left[\mu \mathrm{mol} \mathrm{m}^{-2} \mathrm{~s}^{-1}\right]}\end{array}$ & $\begin{array}{l}\text { WUE } \\
{\left[\mathrm{mmol} \mathrm{mol}^{-1}\right]}\end{array}$ \\
\hline \multirow{2}{*}{ Adult } & Wet & $919 \pm 175^{\mathrm{a} .1}$ & $7.9 \pm 0.4^{\mathrm{a}, 1}$ & $0.28 \pm 0.06^{\mathrm{a}, 1}$ & $52.3 \pm 3.9^{\mathrm{a}, 1}$ & $0.68 \pm 0.04^{\mathrm{a}, 1}$ & $3.7 \pm 0.3^{\mathrm{a}, 1}$ & $5.4 \pm 0.6^{\mathrm{a}, 1}$ \\
& Dry & $1355 \pm 199^{\mathrm{b}, 1}$ & $11.0 \pm 0.5^{\mathrm{b}, 1}$ & $1.34 \pm 0.16^{\mathrm{b}, 1}$ & $61.9 \pm 7.2^{\mathrm{a}, 1}$ & $0.97 \pm 0.07^{\mathrm{b}, 1}$ & $3.2 \pm 0.4^{\mathrm{a}, 1}$ & $4.1 \pm 0.3^{\mathrm{b}, 1}$ \\
\multirow{2}{*}{ Intermediate } & Wet & $911 \pm 178^{\mathrm{a}, 1}$ & $8.8 \pm 0.5^{\mathrm{a}, 1}$ & $0.33 \pm 0.07^{\mathrm{a}, 1}$ & $69.3 \pm 5.1^{\mathrm{a}, 2}$ & $1.11 \pm 0.06^{\mathrm{a}, 2}$ & $4.8 \pm 0.3^{\mathrm{a}, 2}$ & $4.8 \pm 0.8^{\mathrm{a}, 1}$ \\
& Dry & $1269 \pm 197^{\mathrm{b}, 1}$ & $12.8 \pm 0.6^{\mathrm{b}, 2}$ & $1.39 \pm 0.13^{\mathrm{b}, 1}$ & $53.2 \pm 5.5^{\mathrm{b}, 1,2}$ & $0.77 \pm 0.08^{\mathrm{b}, 2}$ & $2.9 \pm 0.4^{\mathrm{b}, 1}$ & $4.0 \pm 0.4^{\mathrm{a}, 1}$ \\
\multirow{2}{*}{ Juvenile } & Wet & $973 \pm 181^{\mathrm{a}, 1}$ & $9.6 \pm 0.6^{\mathrm{a}, 1,2}$ & $0.39 \pm 0.07^{\mathrm{a}, 1}$ & $79.7 \pm 8.2^{\mathrm{a}, 2}$ & $1.70 \pm 0.06^{\mathrm{a}, 3}$ & $5.3 \pm 0.4^{\mathrm{a}, 2}$ & $2.9 \pm 0.6^{\mathrm{a}, 2}$ \\
& Dry & $1402 \pm 194^{\mathrm{b}, 1}$ & $12.2 \pm 0.7^{\mathrm{b}, 2}$ & $1.24 \pm 0.08^{\mathrm{b}, 1}$ & $43.9 \pm 7.8^{\mathrm{b}, 2}$ & $0.67 \pm 0.09^{\mathrm{b}, 2}$ & $3.5 \pm 0.5^{\mathrm{b}, 1}$ & $4.8 \pm 0.4^{\mathrm{b}, 1}$ \\
\hline
\end{tabular}

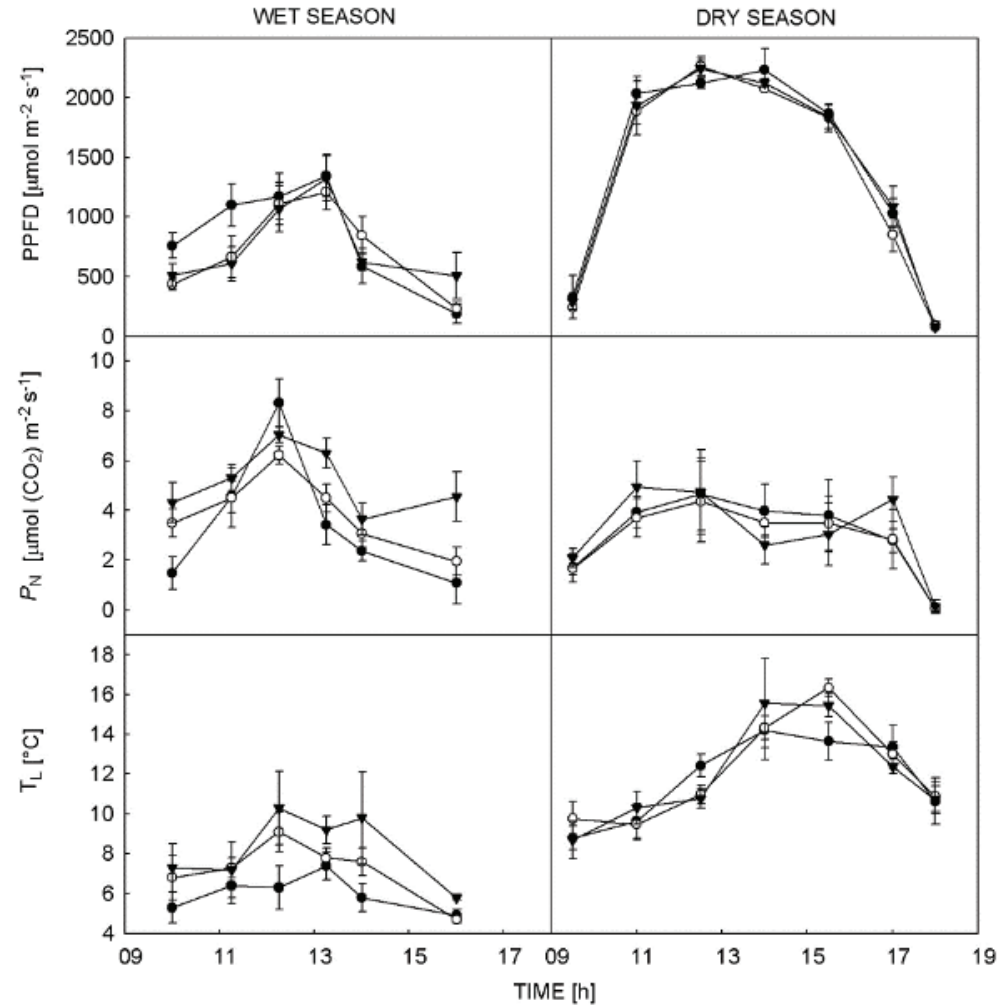

Fig. 2. Wet- and dry season courses for photosynthetic photon flux density (PPFD), net photosynthetic rate $\left(P_{\mathrm{N}}\right)$, and leaf temperature $\left(\mathrm{T}_{\mathrm{L}}\right)$. Results correspond to the mean of three different daily courses taken for each of the seasons. Adults $(\boldsymbol{O})$, intermediate $(\bigcirc)$, juveniles $(\boldsymbol{\nabla})$. Values presented correspond to mean \pm SE $(n=9$ for both wet and dry seasons). a significant increase from wet to dry season (Table 2). The significant seasonal decrease in $P_{\mathrm{N}}$ from one season to the other in intermediate and juvenile stages may be explained by the extremely high incoming radiation inputs from midmorning to midafternoon during the dry season. One can observe from the PPFD- $P_{\mathrm{N}}$ curves (Fig. 3) how $P_{\mathrm{N}}$ values decreased in these two stages at radiation inputs of $2,000 \mu \mathrm{mol} \mathrm{m} \mathrm{m}^{-2} \mathrm{~s}^{-1}$ or above. This decrease in $P_{\mathrm{N}}$ may also be explained by the significant decreases in $g_{\text {s }}$ observed in these two stages (Table 2). Light compensation points were 20.7 and $24.5 \mu \mathrm{mol} \mathrm{m}$ $\mathrm{s}^{-1}$ for adults, 20.3 and $37.6 \mu \mathrm{mol} \mathrm{m} \mathrm{m}^{-2}$ for intermediate and 45.7 and $27.2 \mu \mathrm{mol} \mathrm{m} \mathrm{m}^{-1}$ for juveniles during wet and dry seasons, respectively.

$\mathrm{T}_{\mathrm{L}}$ may also be an important factor determining $P_{\mathrm{N}}$ differences from one season to the other. From $\mathrm{T}_{\mathrm{L}}-P_{\mathrm{N}}$ curves carried out on adult individuals one can determine that optimum $\mathrm{T}_{\mathrm{L}}$ for photosynthesis for C. moritziana was $10.2^{\circ} \mathrm{C}$ (Fig. 4) at maximum $P_{\mathrm{N}}$ of $4.1 \mu \mathrm{mol} \mathrm{m} \mathrm{m}^{-2} \mathrm{~s}^{-1}$. Considering mean $\mathrm{T}_{\mathrm{L}}$ obtained for wet and dry seasons, $P_{\mathrm{N}}$ rates were $3.7 \mu \mathrm{mol} \mathrm{m}{ }^{-2} \mathrm{~s}^{-1}\left(\mathrm{~T}_{\mathrm{L}}=7.9^{\circ} \mathrm{C}\right)$ and $4.0 \mu \mathrm{mol}$ $\mathrm{m}^{-2} \mathrm{~s}^{-1}\left(\mathrm{~T}_{\mathrm{L}}=11.0^{\circ} \mathrm{C}\right)$ for wet- and dry seasons, respectively. These values correspond to a $10 \%$ and $3 \%$ reduction in $P_{\mathrm{N}}$ from the optimum $\mathrm{T}_{\mathrm{L}}$ for wet- and dry seasons, respectively. 


\section{Discussion}

Water relations studies in Andean tropical mountains have suggested that giant rosette plants are not able to resist low $\Psi_{\mathrm{L}}$. Rada et al. (1998) report very high $\Psi_{\mathrm{L}}{ }^{\mathrm{min}}$ for both wet $(-0.6 \mathrm{MPa})$ and dry $(-1.0 \mathrm{MPa})$ seasons in Espeletia schultzii at 4,200 $\mathrm{m}$ a.s.l. in the Venezuelan Andes. Baruch (1979) reports $\Psi_{\mathrm{L}}^{\mathrm{min}}$ of $-1.5 \mathrm{MPa}$ for E. schultzii adult plants at 4,200 $\mathrm{m}$. These authors also describe that a severe stomatal control was necessary to maintain these high $\Psi_{\mathrm{L}}$. Estrada et al. (1991) describe $\Psi_{\mathrm{L}}{ }^{\mathrm{min}}$ for Coespeletia spicata of $-1.6 \mathrm{MPa}$ and $-1.4 \mathrm{MPa}$ for adult and juvenile plants, respectively, and values above $-1.0 \mathrm{MPa}$ for both adult and juveniles of Coespeletia timotensis in the same region of the Andes in which our study was carried out. These authors also suggest a strong stomatal control in C. spicata, while C. timotensis would rely on its efficient hydraulic connections between pith and leaves to maintain positive $\Psi_{\mathrm{L}}$ during the dry season. In a different study, C. timotensis small plants experienced lower $\Psi_{\mathrm{L}}$ compared to taller plants during the dry season, while no differences were observed during the wet season (Goldstein et al. 1985a). These authors report $\Psi_{\mathrm{L}}{ }^{\mathrm{min}}$ of -1.4 to $-1.5 \mathrm{MPa}$ for juveniles (20-30 cm in height) compared to values of $-1.2 \mathrm{MPa}$ for adults $(90 \mathrm{~cm}$ in height). Goldstein et al. (1985a) describe a turgor loss point of $-1.4 \mathrm{MPa}$ for all height classes indicating this species does not have the ability to osmotically adjust. These authors conclude that this inability together with a smaller water-storage capacity during periods of low water availability result in a high risk of mortality in establishing stages for this species. $\Psi_{\mathrm{L}}^{\min }(-1.8$ to $-1.9 \mathrm{MPa}$ for all stages) described in our study are lower compared to those of other giant rosettes of the Andes. Additionally, turgor loss for C. moritziana is reached at a $\Psi_{\mathrm{L}}$ of $-2.3 \mathrm{MPa}$, suggesting that it resists more extreme water-deficit conditions. Schulze et al. (1985) report very low diurnal $\Psi_{\mathrm{L}}$ $(-2.2 \mathrm{MPa})$ for Lobelia telekii, an Afroalpine giant rosette during the dry season. Additionally, these authors report that these low water potentials did not have any effects on leaf conductance. It is important to note that Beck et al. (1984) have described extremely low $\Psi_{\mathrm{L}}(-6.7 \mathrm{MPa})$ in afroalpine giant rosettes when leaves are frozen at night. Since the freezing process involves water movement from intracellular to intercellular spaces in leaves, it is necessary that plants be extremely resistant to water deficits in order to survive. Therefore, it is not surprising that leaf conductance is not affected by low $\Psi_{\mathrm{L}}$ as has been reported by Schulze et al. (1985). In contrast, the Coespeletias do not have the ability to tolerate ice formation; consequently one would not expect these plants to be very resistant to water deficits.

In terms of gas exchange, stomatal control has been described as one of the main mechanisms by which giant rosettes resist low water availability and/or high evapo- rative demand periods in the high Andean environments. In fact, all Coespeletia studies establish important leaf conductance reductions from wet to dry seasons to avoid reaching low $\Psi_{\mathrm{L}}$. Rada et al. (1998) describe reductions from 120 to $40 \mathrm{mmol} \mathrm{m}^{-2} \mathrm{~s}^{-1}$ from wet to dry seasons in E. schultzii in order to maintain $\Psi_{\mathrm{L}}$ above $-1.0 \mathrm{MPa}$. In contrast, our results for $C$. moritziana show no seasonal differences in $g_{\mathrm{s}}$ for adult rosettes while intermediate and juvenile stages do have a stronger stomatal control during the dry season. Schulze et al. (1985) report $g_{\mathrm{s}}$ between 100 and $150 \mathrm{mmol} \mathrm{m}^{-2} \mathrm{~s}^{-1}$ for Lobelia spp. during the dry season. They also show how $g_{\mathrm{s}}$ is more strongly related to VPD and as previously stated $\Psi_{\mathrm{L}}$ did not have an immediate effect on $g_{s}$.

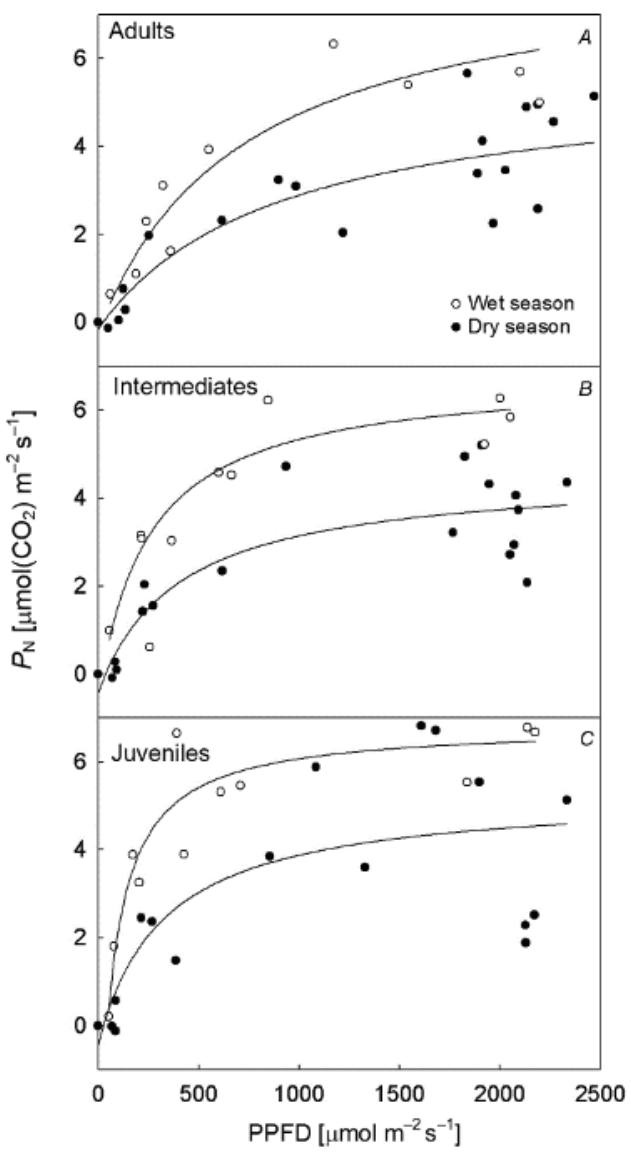

Fig. 3. Photosynthetic photon flux density (PPFD)-net photosynthetic rate $\left(P_{\mathrm{N}}\right)$ curves for $C$. moritziana's three growth stages. Open circles correspond to the wet- and solid circles to the dry season. $(A)$ wet season: $P_{\mathrm{N}}=8.3(-20.7+$ PPFD $) /(-20.7$ $+733.7+$ PPFD $), r^{2}=0.78$; dry season: $P_{\mathrm{N}}=5.6(-24.5+$ PPFD $) /(-24.5+916.7+$ PPFD $), r^{2}=0.71$. (B) wet season: $P_{\mathrm{N}}=6.8(-20.3+\mathrm{PPFD}) /(-20.3+270.5+\mathrm{PPFD}), r^{2}=0.64 ;$ dry season: $P_{\mathrm{N}}=4.6(-37.6+$ PPFD $) /(-37.6+435.5+$ PPFD $)$, $r^{2}=0.72$. (C): wet season: $P_{\mathrm{N}}=6.8(-45.7+$ PPFD $) /(-45.7+$ $117.8+$ PPFD $), r^{2}=0.84$; dry season: $P_{\mathrm{N}}=5.3(-27.2+$ PPFD $) /(-27.2+350.7+$ PPFD $), r^{2}=0.62$. 


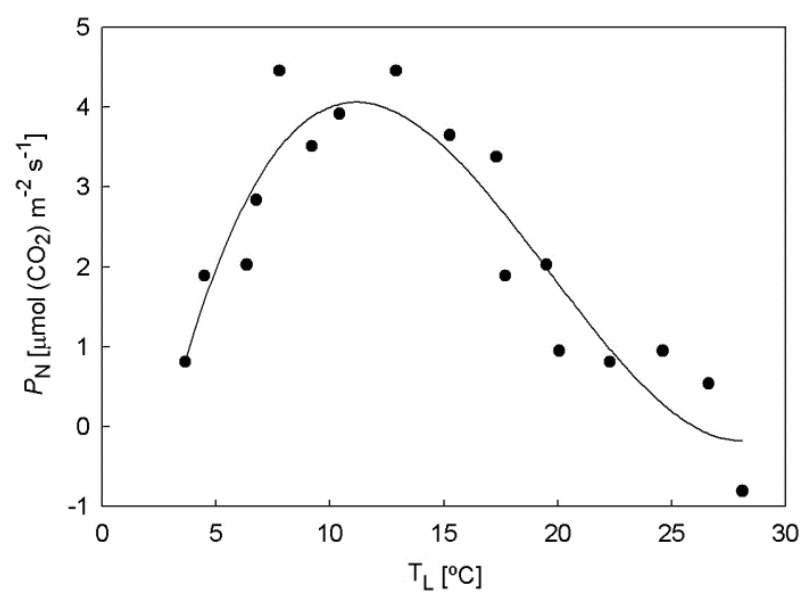

Fig. 4. Leaf temperature $\left(\mathrm{T}_{\mathrm{L}}\right)$-net photosynthetic rate $\left(P_{\mathrm{N}}\right)$ curve for adult plants of Coespeletia moritziana. Optimum temperature for photosynthesis corresponded to $10.2^{\circ} \mathrm{C}$. A fourth order polynomic function was fitted to the data $\left(P_{\mathrm{N}}=-0.00007 \mathrm{~T}_{\mathrm{L}}^{4}+\right.$ $\left.0.0065 \mathrm{~T}_{\mathrm{L}}^{3}-0.208 \mathrm{~T}_{\mathrm{L}}^{2}+2.508 \mathrm{~T}_{\mathrm{L}}-6.064, r^{2}=0.88\right)$.

Maximum $P_{\mathrm{N}}$ of $8 \mu \mathrm{mol} \mathrm{m} \mathrm{m}^{-2} \mathrm{~s}^{-1}$ found in this study for C. moritziana adult plants are comparable to those of C. spicata (Goldstein et al. 1989), and higher than those of C. timotensis (Goldstein et al. 1989) and E. schultzii (Rada et al. 1998), all giant rosettes growing at 4,200 m in the Venezuelan Andes. Both Goldstein et al. (1989) and Rada et al. (1998) describe how, during the dry season, $P_{\mathrm{N}}$ for different adult giant rosettes may fall down to the $\mathrm{CO}_{2}$ compensation point during the day. In the case of $C$. moritziana, $P_{\mathrm{N}}$ remained constant between seasons in adult plants. In the case of the other two stages, even though $P_{\mathrm{N}}$ decreased from the wet to the dry season, it did not reach values close to the $\mathrm{CO}_{2}$ compensation point, therefore suggesting that this species may maintain a more positive leaf carbon balance throughout the year compared to the other giant rosettes studied. Likewise, the wide range of maximum $P_{\mathrm{N}}$ described for giant rosettes in the Andes persists in African and/or Asian giant rosettes. Fetene et al. (1997) observed maximum $P_{\mathrm{N}}$ of 6-7 $\mu \mathrm{mol} \mathrm{m} \mathrm{m}^{-2} \mathrm{~s}^{-1}$ in Lobelia rhynchopetalum, a giant rosette plant growing at $4,000 \mathrm{~m}$ in the tropical alpine regions of Ethiopia. Schulze et al. (1985) describe rates between $8-11 \mu \mathrm{mol} \mathrm{m} \mathrm{m}^{-2} \mathrm{~s}^{-1}$ for afroalpine rosettes of the genus Dendrosenecio spp. and Lobelia spp. during the dry season. While Terashima et al. (1993) measured $P_{\mathrm{N}}$ of $10-16 \mu \mathrm{mol} \mathrm{m} \mathrm{m}^{-2} \mathrm{~s}^{-1}$ and no stomatal restrictions for Rheum nobile, a monocarpic giant rosette, at $4,300 \mathrm{~m}$ in the Eastern Himalaya during the wet season, however no data is presented for the dry season. With respect to optimum temperature for photosynthesis, our result $\left(10.2^{\circ} \mathrm{C}\right)$ contrasts that of $7.9^{\circ} \mathrm{C}$ for E. schultzii (Rada et al. 1992). However, temperature does not seem to be a major limitation since daily mean $\mathrm{T}_{\mathrm{L}}$ for photosynthesis are always above the $90 \%$ for $P_{\mathrm{N}}$ in relation to the optimum $\mathrm{T}_{\mathrm{L}}$ measured for adult plants. Schulze et al.
(1985) mention that maximum $P_{\mathrm{N}}$ for different Lobelia and Dendrosenecio species occur between $8^{\circ} \mathrm{C}$ and $13^{\circ} \mathrm{C}$. In addition, high radiation inputs may be limiting C. moritziana's photosynthetic capacity. As observed in our work, at high radiation inputs $P_{\mathrm{N}}$ decreases. Fetene $e t$ al. (1997) report $\mathrm{CO}_{2}$ uptake inhibition in L. rhynchopetalum at high PPFD. Cui et al. (2004) describe how high radiation induces photoinhibition, limiting photosynthetic carbon gain in Saussurea superba, a dwarf rosette plant of the Qinghai-Tibet Plateau.

With respect to the comparison between life cycle stages, the importance of the pith water storage of the giant rosettes stands out. However, C. moritziana's intermediate and juvenile stages appear to overcome its lack by having higher $g_{\mathrm{s}}$, mainly during early morning and late afternoon hours of the wet season. The ability to maintain low osmotic potentials at turgor loss, even in the wet season, allows these two stages to have higher $g_{\mathrm{s}}$ and higher $P_{\mathrm{N}}$ during both seasons. Even though $P_{\mathrm{N}}$ decreased during the dry season in intermediates and juveniles, mean rates are still very positive $\left(2.9\right.$ and $3.5 \mu \mathrm{mol} \mathrm{m} \mathrm{m}^{-2} \mathrm{~s}^{-1}$, respectively). For instance, E. schultzii growing at 4,200 m in the Venezuelan Andes had maximum and mean $P_{\mathrm{N}}$ of 2.2 and $0.9 \mu \mathrm{mol} \mathrm{m}{ }^{-2} \mathrm{~s}^{-1}$, respectively; almost four times below C. moritziana's dry season rates for any of the stages. According to Fetene et al. (1998), for L. rhynchopetalum adult plants, water relations are not important due to roots that reach the deep soil. However, juveniles, with superficial roots are subjected to severe drought during the dry season. They suggest this would be one of the main reasons why very few individuals survive. Other authors also report a high mortality rate in establishing phases of $C$. timotensis and C. spicata in the high Venezuelan Andes (Estrada and Monasterio 1988, Guariguata and Azócar 1998). All these results point to the importance of the establishing phase as a main filter in the success of plants. However, it is still necessary to study C. moritziana's survival rates in these phases due to its apparent more resistant characteristics under these extreme environments. We suggest that the success of these rosettes depends on how they are able to get away from the most extreme conditions of the ground surface to reach the more favorable conditions well above ground level.

Giant rosettes had been described as having very similar responses to water and temperature stress (Azócar et al. 2000). These authors suggested that under a change in ambient conditions, i.e. more extreme water deficits and/or higher temperature effects, all giant rosettes would be negatively affected, thus jeopardizing this ecosystem's functional stability. Although our intention is not to conclude on this stability, as we are clear that there are many other factors involved, our results do suggest that C. moritziana is capable of resisting, throughout all stages, more extreme conditions than other studied giant rosettes of the tropical high Andes. 


\section{References}

Azócar, A., Rada, F., García-Núñez, C.: [Ecophysiological aspects for the conservation of contrasting tropical ecosystems.] - B. Soc. Bot. Mex. 65: 89-94, 2000. [In Span.]

Baruch, Z.: Elevation differentiation in Espeletia schultzii (Compositae), a giant rosette plant of the Venezuelan paramos. - Ecology 60: 85-98, 1979.

Baruch, Z., Smith, A.P.: Morphological and physiological correlates of niche breadth in two species of Espeletia (Compositae) in the Venezuelan Andes. - Oecologia 38: 7182, 1979.

Beck, E., Schulze, E.D., Senser, M., Scheibe, R.: Equilibrium freezing of leaf water and extracellular ice formation in Afroalpine 'giant rosette' plants. - Planta 162: 276-282, 1984.

Bussmann, R.W.: Vegetation zonation and nomenclature of African mountains - An overview. - Lyonia 11: 41-66, 2006.

Cui, X., Tang, Y., Gu, S., Shi, S., Nishimura, S., Zhao, X.: Leaf orientation, incident sunlight and photosynthesis in the alpine species Suassurea superba and Gentiana straminea on the Qinghai-Tibet Plateau. - Arct. Antarct. Alp. Res. 36: 219-228, 2004.

Estrada, C., Monasterio, M.: [Population Ecology of a giant rosette, Espeletia spicata Sch. Bip. (Compositae), from the Desert Páramo.] - Ecotrópicos 1: 25-39, 1988. [In Span.]

Estrada, C., Goldstein, G., Monasterio, M.: Leaf dynamics and water relations of Espeletia spicata and E. timotensis, two giant rosettes of the desert Paramo in the tropical Andes. Acta Oecol. 12: 603-616, 1991.

Fetene, M., Nauke, P., Lüttge, U., Beck, E.: Photosynthesis and photoinhibition in a tropical alpine giant rosette plant, Lobelia rhynchopetalum. - New Phytol. 137: 453-461, 1997.

Fetene, M., Gashaw, M., Hauke, P., Beck, E.: Microclimate and ecophysiological significance of the tree-like life-form of Lobelia rhynchopetalum in a tropical alpine environment. Oecologia 113: 332-340, 1998.

Field, C., Ball, J.T., Berry, J.A.: Photosynthesis: principles and field techniques. - In: Piercy, R.W., Ehleringer, J., Mooney, H.A., Rundel, P.W. (ed.): Plant Physiological Ecology. Field Methods and Instrumentation. Pp. 209-253. Chapman \& Hall, London 1989.

Goldstein, G., Meinzer, F., Monasterio, M.: The role of capacitance in the water balance of Andean giant rosette species. - Plant Cell Environ. 7: 179-186, 1984.

Goldstein, G., Meinzer, F., Monasterio, M.: Physiological and mechanical factors in relation to size-dependent mortality in an Andean giant rosette species. - Acta Oecol.-Oec. Plant. 6: 263-275, 1985a.

Goldstein, G., Rada, F., Azócar, A.: Cold hardiness and supercooling along an actitudinal gradient in Andean giant rosette species. - Oecologia 68: 147-152, $1985 \mathrm{~b}$.

Goldstein, G., Rada, F., Canales, M.O., Zabala, O.: Leaf gas exchange of two giant caulescent rosette species. - Acta Oecol. 10: 358-370, 1989.

Guariguata, M.T., Azócar, A.: Seed bank dynamics and germination ecology in Espeletia timotensis (Compositae), an Andean giant rosette. - Biotropica 20: 54-59, 1998.

Halloy, S.: The use of convergence and divergente in the interpretation of adaptation in high mountain biota. - Evol. Theor. 6: 232-255, 1983.

Hedberg, O.: Features of afro-alpine plant ecology. - Acta Phytogeogr. Suecica 49: 1-144, 1964.

Hedberg, I., Hedberg, O.: Tropical alpine life forms of vascular plants. - Oikos 33: 297-307, 1979.

Monasterio, M.: [Vegetation formations of the Venezuelan Páramos.] - In: Monasterio, M. (ed.): [Ecological Studies of the Andean Páramos.] Pp. 93-158. Ediciones Univ Los Andes, Mérida, Venezuela, Mérida 1989. [In Span.]

Rada, F., Goldstein, G., Azócar, A., Meinzer, F.: Freezing avoidance in Andean giant rosette plants. - Plant Cell Environ. 8: 501-507, 1985.

Rada, F., Goldstein, G., Azócar, A., Torres, F.: Supercooling along an altitudinal gradient in Espeletia schultzii, a caulescent giant rosette species. - J. Exp. Bot. 188: 491-497, 1987.

Rada, F., González, J., Azócar, A., Briceño, B., Jaimez, R.: Net photosynthesis-leaf temperature relations in plant species with different height along an altitudinal gradient. - Acta Oecol. 13: 535-542, 1992.

Rada, F., Azócar, A., González, J., Briceño, B.: Leaf gas exchange in Espeletia schultzii Wedd, a giant caulescent rosette species, along an actitudinal gradient in the Venezuelan Andes. - Acta Oecol. 19: 73-79, 1998.

Schulze, E.D., Beck, E., Scheibe, R., Ziegler, P.: Carbon dioxide assimilation and stomatal response of afroalpine giant rosette plants. - Oecologia 65: 207-213, 1985.

Smith, A.P., Young, T.P.: Tropical alpine plant ecology. Annu. Rev. Ecol. Syst. 18: 137-158, 1987.

Terashima, I., Masuzawa, T., Ohba, H.: Photosynthetic characteristics of a giant alpine plant, Rheum nobile Hood. f. et Thoms. and of some other alpine species measured at $4300 \mathrm{~m}$, in the Eastern Himalaya, Nepal. - Oecologia 95:194-201, 1993.

Tyree, M.T., Hammel, H.T.: The measurement of the turgor pressure and the water relations of plants by the pressurebomb technique. - J. Exp. Bot. 23: 267-282, 1972.

von Caemmerer, S., Farquhar, G.D.: Some relationships between the biochemistry of photosynthesis and the gas exchange of leaves. - Planta 153: 376-387, 1981. 